\title{
Elevated Swelling-Activated Chloride Current Densities in Hypertrophied Ventricular Myocytes in a Rabbit Heart Failure Model
}

\author{
Hongwei Shi, MD, ${ }^{1,2}$ Zhenming Jiang,MD, ${ }^{1}$ Teng Wang, ${ }^{3}$ Yongting Chen, ${ }^{3}$ Feng Cao, MD ${ }^{3,4,5}$ \\ ${ }^{1}$ Department of Oncology, Renmin Hospital of Wuhan University, Wuhan, China; ${ }^{2}$ Department of Radiation Oncology, Hubei Cancer \\ Hospital, Wuhan, China; ${ }^{3}$ Department of Cardiology, Renmin Hospital of Wuhan University, Wuhan, China; ${ }^{4}$ Cardiovascular Research \\ Institute, Wuhan University, Wuhan, China; ${ }^{5}$ Hubei Key Laboratory of Cardiology, Wuhan, China
}

\section{ABSTRACT}

Background: The status of the swelling-activated chloride channel $\left(\mathrm{I}_{\mathrm{Cl} \text {, swell }}\right)$ during heart failure remains unclear. This study aimed to investigate whether the $\mathrm{I}_{\mathrm{Cl} \text {, swell }}$ activity is altered during heart failure and to determine how the $\mathrm{I}_{\mathrm{Cl} \text {, swell }}$ influences atrial arrhythmias of the failing heart.

Methods: We established a heart failure rabbit model and analyzed the hemodynamic indicators 8 weeks after myocardial infarction, which include left ventricular systolic pressure (LVSP) and left ventricular end-diastolic pressure (LVDEP). Five untreated rabbits and 5 receiving a sham operation served as the control group. Left auricular appendage tissues were obtained and $C L C N 3 \mathrm{mRNA} / \mathrm{CLCN} 3$ protein expression levels were examined by using reverse transcriptionpolymerase chain reaction and Western blot, respectively.

Results: Compared to the control group, the heart failure group showed a significantly decreased LVSP $(14.2 \pm 0.27$ versus $16.9 \pm 0.86 \mathrm{kPa}, P<.05)$ and elevated LVDEP $(2.49 \pm$ 0.30 versus $0.15 \pm 0.03 \mathrm{kPa}, P<.05)$, indicating that myocardial infarction leads to progressive heart failure of rabbits in the heart failure group. CLCN3 mRNA and CLCN3 protein expression were both significantly elevated in the heart failure group compared to the control group $(P<.05)$.

Conclusion: In sum, we propose that the dynamic nature of $\mathrm{I}_{\mathrm{Cl} \text {, swell }}$ upregulation may contribute to the elevated expression of CLCN3 mRNA and CLCN3 protein, resulting in myocardial cell remodeling induced by heart failure. However, further study is needed to investigate the potential functions of $\mathrm{I}_{\mathrm{Cl}, \text { swell }}$, especially the relation between $\mathrm{I}_{\mathrm{Cl} \text {, swell }}$ augmentation and arrhythmia after heart failure.

\section{INTRODUCTION}

In recent decades, the swelling-activated chloride channel $\left(\mathrm{I}_{\mathrm{Cl}, \text { swell }}\right)$ in ventricular myocytes has drawn increasing interest in the field of physiology [Jentsch 1995]. Most of the evidence demonstrated that the chloride $(\mathrm{Cl})$ ion is ubiquitous

Received October 17, 2018; accepted December 3, 2018.

Correspondence: Feng Cao, MD, Department of Cardiology, Renmin Hospital of Wuban University, Fiefang Road 238, Wuban 430060, China; +86-136-27287313 (e-mail:lmcf72@126.com). in living organisms and that $\mathrm{Cl}$ current occurs because of the movements of intracellular and extracellular $\mathrm{Cl}$ ions [Duan 1995]. The activation of $\mathrm{Cl}$ channels could affect the resting potential and action potential duration of the myocardial cell membrane. Heart failure causes important ionic remodeling as well as structural remodeling [Hume 1991]. Recently, evidence indicates that anion channels are involved in the process of remodeling [Hiraoka 1998], but it remains to be understood whether the $\mathrm{I}_{\mathrm{Cl} \text {, swell }}$ are activated during heart failure. Therefore, the aim of this study was to investigate whether $\mathrm{I}_{\mathrm{Cl} \text {, swell }}$ activity is altered during cardiac failure and to determine how the $\mathrm{I}_{\mathrm{Cl} \text {, swell }}$ influences atrial arrhythmias of the failing heart.

\section{IMATERIALS AND METHODS}

\section{Animal Preparation}

New Zealand white rabbits were provided from the Experimental Animal Center at the Medical College of Wuhan University. Twenty healthy adult white rabbits (male or female, $1.5-2.0 \mathrm{~kg}$ ) were randomly assigned into 2 groups: a control group $(\mathrm{n}=10,5$ untreated and 5 receiving a sham operation) and a heart failure group $(\mathrm{n}=10)$.

\section{Heart Failure Model}

The heart failure model was produced as previously described [Liu 2003]. Adult New Zealand white rabbits (1.5$2.0 \mathrm{~kg}$ ) were anesthetized with $3 \%$ sodium pentobarbital $(30 \mathrm{mg} / \mathrm{kg})$ via an indwelling cannula in the abdominal cavity. Rabbits were fixed on the operation table in the dorsal position, and a surface electrocardiogram was recorded. After making a midline muscle and skin incision over the sternum, a left thoracotomy was performed through the $2 \mathrm{nd}-3 \mathrm{rd}$ or $3 \mathrm{rd}-$ 4th intercostal space. The thoracic cavity was gently opened by using a soft tissue retractor with particular care to avoid pneumothorax as a result of pleural injury. The pericardium was sheared by using curved forceps. Subsequently, the heart was completely exposed by suspending the pericardium. After raising the left auricular appendage with forceps, the major ventricular branch of the left coronary artery was ligated $2 \mathrm{~mm}$ from its origin to the cardiac apex. The model of myocardial infarction was considered to be successful when darkening of the blood supply, the presence of areas with 
weakening of pulsation, and electrocardiogram recording of ST-segment elevation were observed macroscopically. As a comparison, the left coronary artery of the rabbits in the sham operation group was not ligated although all other steps were performed in a similar fashion.

\section{Standard Index Determination of Cardiac Failure}

Left ventricular end-diastolic pressure (LVDEP) no less than $2.4 \mathrm{kPa}(18 \mathrm{mmHg})$ was defined as cardiac failure.

\section{Hemodynamic Assessment}

The hemodynamic assessment was undertaken 8 weeks after myocardial infarction, including left ventricular systolic pressure (LVSP) and LVEDP.

\section{CLCN3 mRNA Expression Analyzed by Reverse Transcrip- tion-Polymerase Chain Reaction}

Total RNA was extracted from rabbit cardiac muscle by using TRIzol ${ }^{\circledR}$ Reagent (Invitrogen [Thermo Fisher Scientific, Waltham, MA, USA]) according to the manufacturer's instructions. Briefly, tissue samples in $1 \mathrm{~mL}$ TRIzol reagent per 50-mg tissue were homogenized by using a tissue homogenizer. The lysate was incubated with TRIzol reagent at room temperature for 5 minutes to allow complete dissociation of nucleoprotein complexes, and then $0.2 \mathrm{~mL}$ chloroform per $1 \mathrm{~mL}$ TRIzol reagent was added. The sample was shaken vigorously by hand for 15 seconds and then centrifuged at $12,000 \times \mathrm{g}$ for 15 minutes at $2-8^{\circ} \mathrm{C}$. Four hundred microliters of the colorless supernatant containing the RNA was transferred to a fresh RNase-free tube, and isopropyl alcohol was added and mixed, and then the mixture was maintained at $-20^{\circ} \mathrm{C}$ for $10-15$ minutes. The sample was centrifuged at $12,000 \times \mathrm{g}$ for 10 minutes at $2-8^{\circ} \mathrm{C}$, and the supernatant was discarded. The pellet containing RNA was washed with $75 \%$ alcohol, thoroughly shaken, and then centrifuged at $7500 \times$ $\mathrm{g}$ for 15 minutes at $4^{\circ} \mathrm{C}$. The supernatant was discarded and the pellet was dried. Sufficient RNase-free water was added to dissolve the RNA pellet. TURBO DNA-free ${ }^{\mathrm{TM}}$ DNase (Ambion[Thermo Fisher Scientific, Waltham, MA, USA]) was utilized to eliminate genomic DNA contamination in the RNA sample. Reverse transcription reaction was performed according to the manufacturer's instructions (Invitrogen [Thermo Fisher Scientific, Waltham, MA, USA]). Briefly, the RNA template and all reagents were combined, and reverse transcription proceeded at $70^{\circ} \mathrm{C}$ for 5 minutes, $37^{\circ} \mathrm{C}$ for 60 minutes, and $95^{\circ} \mathrm{C}$ for 6 minutes. Upon completion of reverse transcription, PCR amplification was carried out by using the following parameters: $97^{\circ} \mathrm{C}$ for 5 minutes, 1 cycle; $94^{\circ} \mathrm{C}$ for 30 seconds, $56^{\circ} \mathrm{C}$ for 30 seconds, $72^{\circ} \mathrm{C}$ for 30 seconds, 35 cycles; and $72^{\circ} \mathrm{C}$ for 5 minutes, 1 cycle with the specific primers. Five microliters of PCR products were evaluated by $1.5 \%$ gel electrophoresis and visualized with the ultraviolet spectrophotometer.

The primers sequences were as follows: 5'-CATTG GCGTG TATTC AGC-3' forward and 5'-CATTC CGTCG AGGTC TCA-3' reverse. CLCN3 mRNA expression was semiquantitatively analyzed by the accumulation of the gray scale of each electrophoresis strip.
Hemodynamic Indicators of the Heart Failure Group and the Control Group*

\begin{tabular}{lcc}
\hline & Control Group & Heart Failure Group \\
\hline $\operatorname{LVSP}(\mathrm{kPa})$ & $16.9 \pm 0.86$ & $14.2 \pm 0.27$ \\
$\operatorname{LVEDP}(\mathrm{kPa})$ & $0.15 \pm 0.03$ & $2.49 \pm 0.30$ \\
\hline
\end{tabular}

* Left ventricular systolic pressure (LVSP) was significantly decreased $(P<.05)$, whereas left ventricular end-diastolic pressure (LVEDP) was significantly elevated $(P<.05)$ in the heart failure group compared to the control group.

\section{CLCN3 Protein Expression Analyzed by Western Blot}

After 8 weeks of growth, 100-mg left auricular appendage tissue obtained from the 2 rabbit groups was washed with cold saline and cut into pieces. Tissue samples were homogenized in $1 \mathrm{~mL}$ pre-cooled tissue protein extraction reagent. The supernatant was transferred to a fresh tube, and $200 \mu \mathrm{L} 0.01 \mathrm{~mol} / \mathrm{L}$ Tris buffer (pH 7.6) was added. The sample was then centrifuged at $14,000 \mathrm{rpm}$ for 10 minutes at $4^{\circ} \mathrm{C}$. The total protein concentration of the samples was determined by a modified Bradford assay and then stored at $-70^{\circ} \mathrm{C}$ for further study. Pure proteins were prepared from the sample in a loading buffer containing $5 \times$ SDS and boiled for 10 minutes. Twenty micrograms per lane was applied to $10 \%$ polyacrylamide Bis-Tris gels. The gels were electrophoresed at 120 volts for 60 minutes, and then the proteins were transferred to a nitrocellulose filter by wet electroblotting for 60 minutes at $350 \mathrm{~mA}$. Blots were blocked with $5 \%$ dried skim milk for 60 minutes at room temperature and then incubated overnight at $4^{\circ} \mathrm{C}$ with CLCN3 polyclonal antibody (dilution ratio of 1:300). The membrane was briefly rinsed in Tris-HCl buffer solution (TBS) containing $0.05 \%$ Tween-20 three times for 15 minutes (for each membrane) and then incubated with horseradish peroxidase-conjugated goat anti-rabbit secondary antibody for 1 hour at room temperature on a shaker. The membrane was then briefly rinsed in TBS containing $0.05 \%$ Tween20 three times for 15 minutes (for each membrane), and then incubated with immunoblotting luminescence working solution (ECL reagent, Thermo Fisher Scientific, Waltham, MA, USA) for 5 minutes at room temperature. The protected membrane was then placed in a film cassette with the protein side facing up. Immunoreactive bands densities were analyzed by optical density meter after $\mathrm{x}$-ray film exposure. Relative protein expression level was calculated by comparison to the optical density value of the control group.

\section{Statistical Analysis}

All experimental data were analyzed by using SPSS13.0 (SPSS Inc., Chicago, IL, USA). A t test was used to compare the difference in hemodynamics indicators between the heart failure group and the untreated group. Data are presented as mean \pm SD. $P<.05$ was considered statistically significant. 


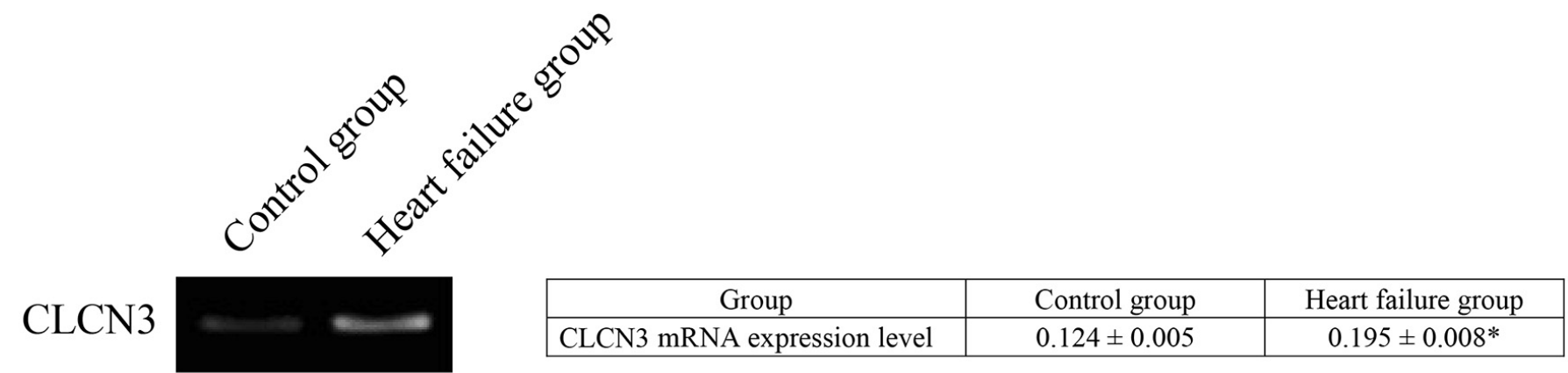

Figure 1. RT-PCR products of the CLCN3 mRNA from the heart failure group and the control group. The heart failure group showed a significantly elevated CLCN3 mRNA expression in the myocardium of the left auricular appendage compared to the control group $(0.195 \pm 0.008$ versus $0.124 \pm 0.005)$. * $P<.05$. RT-PCR, reverse transcription-polymerase chain reaction.

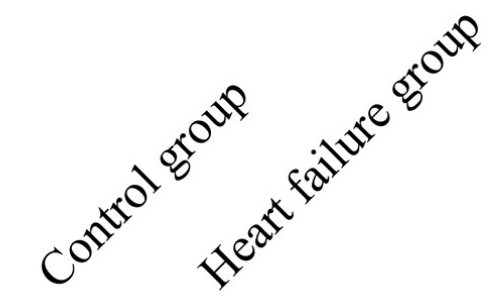

\section{CLCN3}

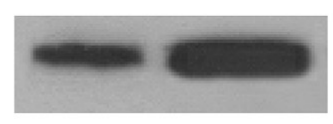

\begin{tabular}{|c|c|c|}
\hline Group & Control group & Heart failure group \\
\hline CLCN3 protein expression level & $0.161 \pm 0.007$ & $0.272 \pm 0.011^{*}$ \\
\hline
\end{tabular}

Figure 2. Western blot analysis of the CLCN3 protein from the heart failure group and the control group. The heart failure group showed a significantly elevated CLCN3 protein expression in the myocardium of the left auricular appendage compared to the control group ( $0.272 \pm 0.011$ versus $0.161 \pm 0.007)$. $* P<.05$.

\section{RESULTS}

\section{Hemodynamic Determination}

The table summarizes the LSVP and the LVEDP of the rabbits in the control group and the heart failure group. As shown in the Table, the heart failure group showed significantly decreased LVSP $(14.2 \pm 0.27 \mathrm{kPa})$ compared to that of the control group $(16.9 \pm 0.86 \mathrm{kPa}, P<.05)$. Further, the heart failure group showed significantly elevated LVEDP $(2.49 \pm 0.30 \mathrm{kPa})$ compared to that of the control group $(0.15 \pm 0.03 \mathrm{kPa}, P<.05)$. The results demonstrated myocardial infarction leads to progressive heart failure of rabbits in the heart failure group.

\section{Changes in CLCN3 mRNA Expression}

Figure 1 provides gel electrophoresis analysis of the reverse transcription-polymerase chain reaction (RT-PCR) product of the $C L C N 3$ mRNA from the 2 groups. As shown in Figure 1, significantly elevated CLCN3 mRNA expression in the myocardium of the left auricular appendage was observed in the heart failure group $(0.195 \pm 0.008)$ compared to the control group $(0.124 \pm 0.005, P<.05)$.

\section{Changes in CLCN3 Protein Expression}

Figure 2 provides Western blot analysis of the CLCN3 protein from the 2 groups. As shown in Figure 2, significantly increased CLCN3 protein expression in the myocardium of the left auricular appendage was observed in the heart failure group $(0.272 \pm 0.011)$ compared to the control group $(0.161 \pm$ $0.007, P<.05)$.

\section{DIscussion}

In the present study, changes in CLCN3 mRNA and CLCN3 protein expression in the rabbit cardiac atrium during heart failure were assessed by RT-PCR and Western blot. Our results showed significantly elevated expression of CLCN3 mRNA and CLCN3 protein in rabbits with heart failure.

CLCN3 encodes a protein kinase $\mathrm{C}$-regulated $\mathrm{Cl}$ channel involved in regulating cell volume and was firstly cloned and characterized by Kawasaki and Borsani [Rouet-Benzineb1996; Duan 2004]. CLCN3 is present in the plasma membranes of most mammalian cells and plays major roles in cell volume homeostasis regulation. CLCN3, expressed mainly in the cardiac atrium, triggers the activation of $\mathrm{I}_{\mathrm{Cl}}$, swell: Generally, $\mathrm{I}_{\mathrm{Cl}_{\text {s swell }}}$ is activated with increased cell volume and inactivated when cells are placed in an iso-osmolar solution [Clemo 1999]. In such a case, the change of cell volume may induce activation and inactivation of the $\mathrm{Cl}$ channel to initiate a $\mathrm{Cl}$ current, which contributes to ion and solute 
exchange in mammalian myocardial cells during metabolic activities. In addition to changes in cell volume, isoproterenol may also potentially enhance the activation of the $\mathrm{Cl}$ current [Clemo 1998].

$\mathrm{I}_{\mathrm{Cl}, \text { swell }}$ is primarily located in the cardiac atrium and sinus node cells. Therefore, we hypothesize that it may play a role in the electrical activity of cardiac atrium cells and rhythm activity of sinus node cells. Recent studies using multiple approaches to examine the functional role of $\mathrm{Cl}$ channels in the context of health and disease have demonstrated that the $\mathrm{Cl}$ channel might contribute to the following: (1) arrhythmogenesis in myocardial injury; (2) cardiac ischemic preconditioning; and (3) the adaptive remodeling of the heart during myocardial hypertrophy and heart failure [Duan 2005]. Clemo et al reported that congestive heart failure (CHF) altered the set point and magnitude of $\mathrm{I}_{\mathrm{Cl} \text {, swell }}$ and resulted in its persistent activation [Wu 2005]. They previously observed analogous regulation of mechanosensitive cation channels in the same CHF model and concluded that mechanosensitive anion and cation channels may contribute to the electrophysiological and contractile derangements in CHF [Duan 2013]. The activation of $\mathrm{I}_{\mathrm{Cl} \text {, swell }}$ can initiate $\mathrm{Cl}$ inflow and promote repolarization in stage II and III action potentials, resulting in the shortening of the action potential duration and effective refractory period. Through the depolarization of diastolic potential, the conduction velocity was decelerated, facilitating the formation of reentry. Therefore, we propose that $\mathrm{I}_{\mathrm{Cl} \text {, swell }}$ may play a role in the arrhythmogenesis. Akar et al reported that intracellular $\mathrm{Cl}$ accumulation may play a role in atrial fibrillation (AF) pathogenesis by causing resting membrane depolarization and effective refractory period reduction [Borsani 1995]. In a study on cardiac atrium CLCN3 gene expression during AF, Du et al found that upregulation of CLCN3 may result in the shortening of the effective refractory period of action potential and that activation of $\mathrm{Cl}$ channels may stimulate the occurrence of reentry arrhythmias, which may play an important role in the development and maintenance of AF [Du 1997].

It has been reported by Demion et al that human atrial myocytes express an outwardly rectifying $\mathrm{Cl}$ channel that is sensitive to protein kinase C (PKC) activation [Wang 2006]. This channel shares biophysical and pharmacological properties with the swelling-activated $\mathrm{Cl}$ current implicated in cardiac pathologies such as myocardial ischemia and dilated cardiomyopathies. Further, hypotonic stimulation and cellular swelling may induce and outwardly rectify the $\mathrm{Cl}$ channel, suggesting that the $\mathrm{Cl}$ channel could be activated by elevated atrial pressure during heart failure or myocardial ischemia [Demion 2006]. In our present study using the myocardial infarction-induced heart failure model, we observed significantly elevated CLCN3 mRNA and CLCN3 protein expression in the heart failure group compared to the control group. Though the mechanism of $\mathrm{I}_{\mathrm{Cl} \text {, swell }}$ activation is still unknown, some evidence suggested that the highly selective PKC inhibitor-bisindolylmaleimideblocked the effects of norepinephrine on $\mathrm{I}_{\mathrm{Cl} \text {, swell }}$ [Schmidt 1996]. Further, in a heart failure model produced by left ventricular pressure and volume overload, PKC activity and expression of $\mathrm{Ca}^{2+}$-dependent $\mathrm{PKC}$ isoforms were decreased [Pye 1996].

It is well accepted that heart failure is one of the most important risk factors for AF. The occurrence rate of $\mathrm{AF}$ is up to $10 \%-35 \%$ in heart failure patients. Ionic remodeling is a prominent pathological and physiological characteristic during heart failure. It has been found that current density and molecular expression in several major repolarization potassium channels were significantly decreased or downregulated. The effect and significance of $\mathrm{I}_{\mathrm{Cl} \text {, swell }}$ during heart failure in humans is poorly understood. However, it has been reported in the model of myocardial hypertrophy of aortic coarctation in mice that disruption of the CLCN3 gene in mice facilitates heart failure during pressure overload, suggesting that activation of $\mathrm{I}_{\mathrm{Cl} \text { swell }}$ may play an important role in cardiac adaptability and remodeling during pressure overload [Akar 2003]. Activation of $\mathrm{I}_{\mathrm{Cl} \text {, swell }}$ may cause significant changes in action potential duration and intracellular $\mathrm{Ca} 2+$ concentration, as well as the normal excitation-contraction coupling and cardiac hemodynamics function [Kawasaki 1994]. In the present study, our findings revealed that upregulation of $C L C N 3$ mRNA and CLCN3 protein expression after heart failure may lead to augmentation of $\mathrm{I}_{\mathrm{Cl} \text {, swell }}$ and shortening of the effective refractory period and electrical remodeling of the cardiac atrium, suggesting $\mathrm{I}_{\mathrm{Cl} \text {, swell }}$ plays a role in atrial arrhythmogenesis after heart failure.

In sum, we propose that the dynamic nature of $\mathrm{I}_{\mathrm{Cl} \text {, swell }}$ upregulation may contribute to the elevated expression of CLCN3 3 RNA and CLCN3 protein, resulting in myocardial cell remodeling induced by heart failure. However, further study is needed to investigate the potential functions of $\mathrm{I}_{\mathrm{C}}$ swell, especially the relation between $\mathrm{I}_{\mathrm{Cl} \text {, swell }}$ augmentation and arrhythmia after heart failure.

\section{REFERENCES}

Akar JG, Everett TH, Ho R, et al. 2003. Intracellular chloride accumulation and subcellular elemental distribution during atrial fibrillation. Circulation 107:1810-5.

Borsani G, Rugarli EI, Taglialatela M, Wong C, Ballabio A. 1995. Characterization of a human and murine gene (CLCN3) sharing similarities to voltage-gated chloride channels and to a yeast integral membrane protein. Genomics 27:131-41.

Clemo HF, Stambler BS, Baumgarten CM. 1998. Persistent activation of a swelling-activated cation current in ventricular myocytes from dogs with tachycardia-induced congestive heart failure. Circ Res 83:147-57.

Clemo HF, Stambler BS, Baumgarten CM. 1999. Swelling-activated chloride current is persistently activated in ventricular myocytes from dogs with tachycardia-induced congestive heart failure. Circ Res 84:157-65

Demion M, Guinamard R, EI Chemaly AE, Rahmati M, Bois P. 2006. An outwardly rectifying chloride channel in human atrial cardiomyocytes. J Cardiovasc Electrophysiol 17:60-8.

Du XY, Sorota S. 1997. Cardiac swelling-induced chloride current depolarizes canine atrial myocytes. Am J Physiol 272(4 Pt 2):H1904-16.

Duan D, Fermini B, Nattel S. 1995. $\alpha$-Adrenergic control of 
volume-regulated $\mathrm{Cl}^{-}$currents in rabbit atrial myocytes: characterization of a novel ionic regulatory mechanism. Circ Res 77:373-93.

Duan D, Liu LL, Wang GG, et al. 2004. Cell volume-regulated ion channels and ionic remodeling in hypertrophied mouse heart. J Card Fail 10(4 suppl):S72.

Duan DD. 2013. Phenomics of cardiac chloride channels. Compr Physiol 3:667-92.

Duan DY, Liu LL, Bozeat N, et al. 2005. Functional role of anion channels in cardiac diseases. Acta Pharmacol Sin 26:265-78.

Hiraoka M, Kawano S, Hirano Y, Furukawa T. 1998. Role of cardiac chloride currents in changes in action potential characteristics and arrhythmias. Cardiovasc Res 40:23-33.

Hume JR, Harvey RD. 1991. Chloride conductance pathways in heart. Am J Physiol 261(3 Pt 1):C399-412.

Jentsch TJ, Günther W, Pusch M, Schwappach B. 1995. Properties of voltage-gated chloride channels of the CLC gene family. J Physiol 482:19S-25S.

Kawasaki M, Uchida S, Monkawa T, et al. 1994. Cloning and expression of a protein kinase $\mathrm{C}$-regulated chloride channel abundantly expressed in rat brain neuronal cells. Neuron 12:597-604.

Liu LL, Ye L, McGuckin C, Hatton WJ, Duan D. 2003. Disruption of Clcn3 gene in mice facilitates heart failure during pressure overload. J Gen Physiol 122:33A.

Pye MP, Black M, Cobbe SM. 1996. Comparison of in vivo and in vitro haemodynamic function in experimental heart failure: use of echocardiography. Cardiovasc Res 31:873-81.

Rouet-Benzineb P, Mohammadi K, Pérennec J, Poyard M, Bouanani NE, Crozatier B. 1996. Protein kinase C isoform expression in normal and failing rabbit hearts. Circ Res 79:153-61.

Schmidt C, Schwendenwein I, Wieselthaler G, et al. 1996. Pharmacologically induced heart failure for the evaluation of circulatory assistance. Artif Organs 20:685-8.

Wang J, Xu H, Sun X, Niu W. 2006. Pharmacological and biophysical properties of swelling-activated chloride channel in mouse cardiac myocytes. Chin J Physiol 49:126-31.

Wu JB, Xu CX, Zhang JC, Chen L, Lin LF, Hu XZ. 2005. [Study of chloride channel $\mathrm{ClC}-3$ gene expression in patient with atrial fibrillation]. Chin J Clin Pharmacol Ther 10:651-4. Chinese. 